\title{
Conjunctival Melanoma cT3c TNM Finding v8
}

National Cancer Institute

\section{Source}

National Cancer Institute. Conjunctival Melanoma CT3C TNM Finding v8. NCI Thesaurus. Code $C 140577$.

Conjunctival melanoma with tumor of any size invading the orbit. (from AJCC 8th Ed.) 